\title{
Kształtowanie się parametrycznego znaczenia przymiotnika ogromny - ogląd diachroniczny ${ }^{1}$
}

Słowa kluczowe: historia języka polskiego, etymologia, słowotwórstwo historyczne, semantyka historyczna.

doi: http://dx.doi.org/10.31286/JP.101.4.3

\section{Wstęp}

Celem artykułu jest przedstawienie rozwoju słowa ogromny, który z polisemicznego przymiotnika zachowującego znaczenie etymologiczne w XVI-wiecznej polszczyźnie przekształcił się we współczesny przymiotnik parametryczny. Przyjmujemy rozumienie przymiotników parametrycznych za Romanem Laskowskim, według którego są to przymiotniki relatywne oznaczające „pewne właściwości (parametry) fizyczne przedmiotów” (1977: 327). Specyfika przymiotnika ogromny na tle innych przymiotników parametrycznych polega na tym, że należy on do grupy „biegunowych” przymiotników tego typu, czyli takich, które oznaczają „krańcowe wartości w przestrzeni semantycznej wyznaczonej przez daną parę antonimiczną" (obok innych, takich jak np.: olbrzymi, malutki, znikomy) (Laskowski 1977: 332).

Wykorzystując materiał zawarty w słownikach dokumentujących dawną polszczyznę, chcemy pokazać, jakie czynniki wpłynęły na tę zmianę i dzięki jakim mechanizmom mogła ona zajść. W analizach będziemy się kierować zasadami wypracowanymi w badaniach historycznosłowotwórczych (Kleszczowa (red.) 1996) i semantyce historycznej ${ }^{2}$, a zatem ważne będą dla nas dane wynikające ze znaczenia etymologicznego leksemu oraz z jego budowy morfologicznej. Przedstawiony cel pozwala przyjąć następującą kompozycję artykułu: dokonamy

\footnotetext{
* magdalena.pastuch@us.edu.pl; ORCID: oooo-ooo1-6960-7191

** barbara.mitrenga@us.edu.pl; ORCID: oooo-ooo1-9389-8152

1 Współautorstwo obejmuje wszystkie etapy pracy nad artykułem, a wkład każdej z autorek w jego powstanie jest równy. $2 \mathrm{~W}$ przypadku badań historycznosemantycznych trudno wskazać jedno źródło metodologiczne. Inspiracją były dla nas m.in. prace: Pawelec 2003, Mitrenga 2014. Warto także przywołać klasyczną już pozycję Danuty Buttler (1978), w której autorka przedstawia typologie zmiany semantycznej, ilustrując poszczególne typy wieloma przykładami. Wśród omawianych przez Buttler przymiotników znalazło się zaledwie kilka parametrycznych (duży, głęboki, gorący, twardy, wysoki, zimny), ale w żadnym z tych przypadków nie analizuje się znaczenia parametrycznego. Wyrazy te omawiane są zwykle w kontekście zjawiska synestezji. Inny punkt wyjścia (onomazjologiczny) przyjęła w swoich rozważaniach Mariola Jakubowicz (2010) - wśród analizowanych przez nią grup pojęciowych mamy tylko jedną, której można przypisać wartość parametryczną ( gruby - chudy), jednakże ze względu na przyjęte w pracy założenia nie jest ona opisana jako parametryczna.
} 
analizy danych etymologicznych, a później zaprezentujemy semantykę i słowotwórcze otoczenie interesującego nas przymiotnika w polszczyźnie. Na podstawie tych informacji dociekać będziemy, co doprowadziło do zmiany jego znaczenia.

\section{Etymologiczny ogląd przymiotnika ogromny}

W rozważaniach wstępnych przyjęłyśmy, że podstawowym celem prowadzonych badań jest wskazanie procesów, które doprowadziły do współczesnego statusu przymiotnika ogromny, mającego w najnowszych słownikach wartość wyłącznie parametryczną, por.: a. 'mający wielkie rozmiary; wielki, olbrzymi, gigantyczny'; b. 'znaczny pod względem liczby, ilości, wartości; wielki, olbrzymi'; c. 'o uczuciach, pojęciach, zjawiskach itp.; występujący w wysokim stopniu, w wielkim natężeniu, w dużym zakresie; olbrzymi, wielki, silny, intensywny' (USJP) oraz 'mający tak dużą wielkość, intensywność lub zakres, że zwraca uwagę mówiącego' (WSJP PAN). Oznacza to, że jego inwariantne, utrwalone leksykograficznie znaczenie odnosi się wyłącznie do parametryzacji pojęć, zjawisk czy uczuć.

Kwerenda w dawnych źródłach słownikowych pokazuje, że - inaczej niż typowe przymiotniki parametryczne (np. $d u \dot{z} y$, mały) - ogromny w początkach polszczyzny występuje jako przymiotnik, w którym kontynuowana jest wartość leksykalna prasłowiańskiego rdzenia ${ }^{*}$ grom ${ }^{3}$. Podział morfologiczny przymiotnika ogromny będzie przedmiotem opisu w dalszej części artykułu. W tym miejscu zwrócimy uwagę na morfem leksykalny (-grom-), który wywodzi się z prasłowiańszczyzny. Zależność semantyczna pomiędzy rdzeniem * grom- a przymiotnikiem ogromny nie jest z synchronicznego punktu widzenia czytelna.

Polskie źródła etymologiczne są bardzo zróżnicowane, zarówno jeśli chodzi o czas powstania, jak i o przyjęte podstawy metaleksykograficzne, jednakże dla pełności obrazu warto je wszystkie uwzględnić, także po to, aby porównać dane i wskazać na różnice oraz podobieństwa w poszczególnych opisach.

Aleksander Brückner (sBr) umieszcza przymiotnik ogromny w haśle grom, uznając tym samym wspólnotę semantyczną prasłowa grom i jednostek takich jak: gromowy, gromić, gromiwać; zgromić; ogrom, ogromny, ogromność; pogrom; rozgromić; gromki, gromny; gromnica. Według autora możliwy jest związek z greckim chromos 'wrzawa', niemieckim Gram 'złość' czy litewskim gramēti 'gruchnąć (o ziemię)'. Interesujący nas przymiotnik tworzy też w tym słowniku odrębne hasło, w którym Brückner przytacza formę ohromny zaczerpniętą z twórczości Mikołaja Reja, sugerując, że to bohemizm. Współczesne źródło (Basaj, Siatkowski 2006) potwierdza, że postać z $h$ (ohromny) pojawiająca się w XVI wieku jest z pewnością bohemizmem ${ }^{4}$.

Słownik Franciszka Sławskiego został opracowany do hasła $\nmid \dot{z} y w y$, a zatem nie mamy możliwości, aby poznać ustalenia autora odnoszące się do przymiotnika ogromny - warto jednak przyjrzeć się hasłu grom (sEsł). Znaczenie podstawowe to 'piorun, grzmot', a prasłowiańska postać została zrekonstruowana jako ${ }^{\star}$ groms < ie. ${ }^{\star}$ ghromo-s. Na tym samym rdzeniu oparty jest czasownik grzmieć. Podobnie jak dużo wcześniej Brückner, także Sławski

3 Etymologii gromu poświęcony został artykuł Krzysztofa T. Witczaka (2020).

4 Ustalenia te były już wyrażane w opracowaniach wcześniejszych (Siatkowski 1965: 60). 
przywołuje grecki leksem o znaczeniu 'wrzawa, trzask, rżenie' i również mamy tu odniesienie do litewskiego czasownika o znaczeniu 'padać z hałasem'. W haśle jest odesłanie do przymiotnika ogromny. Odrębnymi hasłami, choć powiązanymi wspólnym pochodzeniem, są u Sławskiego m.in. gromić, gromki i gromnica. Wszystkie one zawierają, według autora, rdzeń * grom-, choć odmienne były ich bezpośrednie podstawy. Co ciekawe, w wartości semantycznej zawsze pojawia się odniesienie do grom 'piorun': gromić 'bić, zadawać porażkę, surowo strofować < 'uderzać jak gromem' > 'razić, zwyciężać. Z kolei gromki 'głośny, donośny’ powstało od grom tak samo jak krewki od krew. Jest to, jak twierdzi Sławski, wyraz związany ze wschodnią Słowiańszczyzną, a pierwsze użycie w języku białoruskim wskazuje na pożyczkę z rosyjskiego grómkij. Gromnica zaś wywodzi się od rzadkiego przymiotnika gromny, odnotowanego ze znaczeniem 'huczny, grzmiący'. I tutaj związek semantyczny jest bardzo wyraźny, bo gromnica to świeca, którą zapalano, aby odpędzić groźne dla człowieka gromy. Jak widać dominują w tej charakterystyce trzy elementy: 'głośność, hałas', 'groza, strach (przed hałasem)', 'siła (uderzenia gromem)'.

Warto również wspomnieć o interpretacji Andrzeja Bańkowskiego (2000), który zalicza przymiotnik ogromny do XVI-wiecznych poetyzmów i uznaje, że rosyjski ogrómnyj (огромный) jest późnym polonizmem. Łączy go z podstawą ogromić, która z kolei pochodzi od ogrom. W żadnym z tych haseł nie został przywołany wprost rdzeń * grom-, a jedyną wskazówką, która prowadzi do gromu, może być definicja: 'przerażający, zwłaszcza swoją donośnością (o krzyku, biciu w bębny itp.)', bo leksem grom definiowany jest jako 'grzmot' i wywodzony z psł. * gromz. Podobnie jak Brückner odsyła Bańkowski do greki i litewskiego.

Wiesław Boryś (SBo) również nie zestawia w jednym artykule wyrazów grom i ogromny. Przymiotnik znalazł się w haśle ogrom jako regularny pod względem morfologicznym derywat od tego rzeczownika o znaczeniu 'duże rozmiary, wielkość, wielka ilość czegoś, jednakże dane etymologiczne wskazują na pochodność od czasownika ogromić. To znaczenie obecne jest w polszczyźnie dopiero od XVII wieku. Ważne dla dociekań semantycznych są też podawane przez W. Borysia odwołania do danych innosłowiańskich: staroczeskie ohrom 'grzmot, huk; przestrach', ohroma 'napad, uderzenie; nieszczęście, zmartwienie', słowackie dialektalne ohroma 'kupa' czy ukraińskie dialektalne ohróma 'niezwykła wielkość, wielka ilość.

Jak wynika z powyższych informacji, już na wczesnym etapie rozwoju polszczyzny mamy do czynienia ze współwystępowaniem dwóch elementów semantycznych: 'wielkość i 'głośność (powodująca trwogę, strach)'. W dalszym ciągu analiz etymologicznych wrócimy jeszcze do wartości semantycznych, jakie niesie ten rdzeń w innych językach słowiańskich. W podobny sposób opracowane zostało hasło ogrom (hasła ogromny nie ma) w Polskim słowniku etymologicznym Witolda Mańczaka (sMań). Autor wymienia staroczeski ohrom 'grzmot'i ukraińską dialektalną postać ohroma 'niezwykła wielkość, odsyłając do gromić, które interpretuje jako derywat od ${ }^{\star}$ gromı ' grzmot'. W tym ostatnim haśle przywołane są, podobnie jak u innych etymologów, związki z litewskim, greckim oraz niemieckim, które wskazują na związek semantyczny z głośnym dźwiękiem.

Przegląd polskich słowników etymologicznych zobowiązuje, aby sięgnąć do źródeł innosłowiańskich, ponieważ losy wspólnego językom słowiańskim rdzenia * grom- nie są oczywiste 
i wskazują na różny stopień utrwalenia się jego podstawowej wartości semantycznej oraz na różne ścieżki rozwojowe. Max Vasmer (1950-1958) w haśle гpoм wskazuje na pochodność przymiotnika ogromny od tego właśnie leksemu, choć w definicji mamy odwołanie tylko do doznań dźwiękowych, nie ma natomiast mowy o wartości odnoszącej się do wielkości. Podobnie jest z przymiotnikiem gromki ('głośny'), który według niego w polszczyźnie pojawił się pod wpływem języka rosyjskiego. W tym słowniku w haśle огромный nie podaje się гром jako słowa podstawowego, natomiast wskazuje się na związek ze znaczeniem 'obarczyć, obciążyć5. Autor, powołując się również na Brücknera, przytacza słowo gromada. Te związki są jednak wątpliwe i najprawdopodobniej mamy tu do czynienia z innym rdzeniem, wywodzącym się z praindoeuropejskiego pierwiastka *ger- 'zgarniać, zbierać' - stąd łacińskie gremium (SBo). We współczesnym języku ukraińskim przymiotnik ogromny nie istnieje ${ }^{6}$, jednakże ESUM notuje rzeczownikową formację ogroma (огрома), która jest nośnikiem znaczenia 'dużo, wielka ilość,

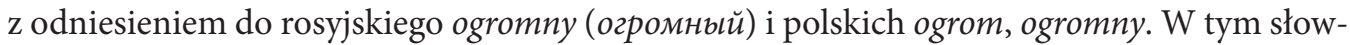
niku za oczywiste uznaje się powiązanie z gromada, a zestawianie z grom za niedostatecznie uzasadnione. W haśle gromada (громадa) potwierdzony został związek z ie. ${ }^{\star}$ grem- < ${ }^{*}$ ger-.

Natomiast w Èss Â przymiotnik ogromny nie został w ogóle odnotowany. Nie pojawia się on również w haśle ^ gromø, które odsyła tylko do znaczenia 'piorun, grzmot. We wszystkich derywatach pochodnych od tego rdzenia i odnotowanych w tym słowniku jako odrębne hasła ( ${ }^{*}$ gromovz $(j b),{ }^{*}$ grombnz $(j b),{ }^{*}$ gromiti) wskazuje się na związek ze zjawiskiem atmosferycznym (grzmieć)', choć możliwe są również użycia metaforyczne (por. polskie gromić 'ostro upominać, surowo krytykować; strofować, kajać, karcić'; przestarzałe 'zadawać porażkę; zwyciężać, rozbijać' (SJPDor, USJP) czy ros. громиmь 'bić).

Wydaje się zatem, że ogromny z właściwą polszczyźnie semantyką związaną z wielkością nie był wspólny całej Słowiańszczyźnie. France Bezlaj w słoweńskim słowniku etymologicznym (1982), omawiając formę ogrómen ('čezmerno velik'), pisze o przejęciu leksemu z innych języków słowiańskich. Powołując się na Franca Miklošiča, potwierdza pochodność od * grom-, jednakże podaje również drugą hipotezę, tę, która pojawiła się u Vasmera i pośrednio u Brücknera ${ }^{7}$, czyli możliwość pochodności od gromada. Bezlaj nie opowiada się jednoznacznie za jedną bądź drugą interpretacją. Również w serbsko-chorwackim słowniku etymologicznym (Skok 1971) sygnalizowana jest wątpliwość co do pochodzenia przymiotnika ogroman - nie ma odrębnego hasła mu poświęconego, ale pojawia się on w haśle gramada, w którym autor sugeruje, że w przymiotniku ogroman rdzeń grom - (z gromada, gramada) skrzyżował się z grom (takim jak w $\mathrm{grm}$, $\mathrm{eti}^{8}$ ). Czeski ohromný pochodny jest według Jiřiego Rejzeka (2001) jednoznacznie od ohromit, a to od hrom, który z kolei interpretowany jest jako derywat rzeczownikowy od hřmĕt, hřmít. Natomiast Václav Machek (1957) inaczej - słowo ohromný łączy z gromada

5 Podany w haśle czasownik огромонить tłumaczony jest synonimicznie jako обременить.

6 Zob. http://ukrlit.org/slovnyk/\%Do\%BE\%Do\%B3 (dostęp: wrzesień 2020 - styczeń 2021); używany jest tylko na wschodzie Ukrainy, najprawdopodobniej pod wpływem języka rosyjskiego.

7 W haśle gromada mamy informację, że przyrostek - $d$ ma znaczenie zbiorowe, ale autor hipotezę o pochodności od grom uznaje za wątpliwą, pisząc: „[...] ale jakiż pień, czy od gromu (por. ogromny = gromadnyj rus.)?” (sBr).

8 Przyjmujemy zapis taki jak w słowniku Petara Skoka. 
i pierwiastek semantyczny 'duża ilość wysuwa na plan pierwszy, nie wspominając o pochodności od rdzenia * grom-, co potwierdzone jest w haśle hromada, gdzie mówi o prawdopodobnym związku hromady z ohromnym.

Jak wynika z powyższego przeglądu, opinie na temat pochodzenia przymiotnika ogromny nie są zgodne ${ }^{9}$. Śledząc drogę przekształceń od przymiotnika nieparametrycznego do parametrycznego, należałoby uwzględniać obie hipotezy - można by nawet uznać, że łączenie z praindoeuropejskim pierwiastkiem * ger- 'zgarniać, zbierać jest dość kuszące, bo pozwoliłoby prosto wyjaśnić obecność w przymiotniku ogromny elementów semantycznych odnoszących się do wielkości czy ilości opisywanych przedmiotów. Bardziej uzasadnione jest jednak uznanie ustaleń poczynionych przez autorów SP, którzy zdecydowali się na odrębny opis obu rdzeni ( ${ }^{\star}$ grem- w haśle ${ }^{\star}$ gromada, ${ }^{\star}$ grom- w haśle * gromz), wskazując na odmienne ich pochodzenie. Prasłowiański ${ }^{\star}$ groms interpretowany jest jako nomen actionis $>$ nomen acti do grbměti i przypisywana jest mu wartość związana z dźwiękiem (huk, hałas, wrzask). Na tym samym rdzeniu oparte są leksemy: ${ }^{\star}$ gromět $i,{ }^{*}$ gromiti, ${ }^{\star}$ gromotati, ${ }^{*}$ gromotz, ${ }^{*}$ gromovo, ${ }^{*}$ gromınz (SP). W większości artykułów hasłowych mamy bezpośrednie odniesienia do zjawiska atmosferycznego, a tylko w jednym ( ${ }^{*}$ gromiti) poza znaczeniem 'grzmieć, huczeć pojawia się, ukształtowane najprawdopodobniej na zasadzie przeniesienia semantycznego, znaczenie 'zadawać porażkę, rozbijać, zwyciężać, unicestwiać, niszczyć, działać jak grom'. Natomiast gromada wywodzona jest od ie. rdzenia * grem- < * ger- 'zgartywać, zbierać', który ma kontynuację w łacińskim gremium. Autorzy hasła podają wiele słowiańskich kontynuantów tego rdzenia, jednak nie potwierdzają łączności z ${ }^{\star}$ gromı.

Zgodnie z rozumieniem terminu „perspektywiczna ewolucja” (Kleszczowa 1998: 10), które zakłada, że porównywanie odległych stanów języka daje większe możliwości obserwowania tendencji rozwojowych języka, uzasadnionym zabiegiem jest odniesienie się do stanu współczesnego w językach słowiańskich - może to pokazać, czy wartość semantyczna wskazanych rdzeni utrwaliła się w innych językach i czy kierunki rozwojowe są wspólne dla całej Słowiańszczyzny. Przedmiotem naszego zainteresowania jest polszczyzna, a dane innosłowiańskie mają charakter wyłącznie pomocniczy.

Przymiotnik oparty na rdzeniu * grom- notują słowniki języków rosyjskiego, słowackiego oraz języków południowych (bułgarski, chorwacki, serbski, czarnogórski, bośniacki, słoweński). W ukraińskim nie używa się przymiotnika, ale istnieje polisemiczna rzeczownikowa for-

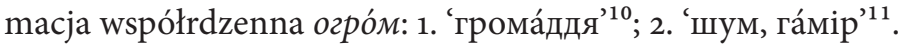

Innosłowiańskie dane leksykograficzne pokazują, że nie we wszystkich językach istnieje współcześnie przymiotnik oparty na prasłowiańskim rdzeniu, ale jeśli istnieje, to ma znaczenie parametryczne ${ }^{12}$, a znaczenie etymologiczne związane $\mathrm{z}$ wartością semantyczną

\footnotetext{
9 Stanisław Kochman pisze wprost: „Jedynie realna jest etymologia łącząca przymiotnik ogromny z grom [...]” (1975: 101). 10 Rzeczownik zbiorowy, który oznacza: obiekty, budowle i w ogóle wszystko, co charakteryzuje się dużym rozmiarem, objętością.

11 'szum, hałas'.

12 Np. chor. ogroman uspjeh; słoweń. ogromne količine denarja; bułg. Огромен период от време; ros. Человек огромного pocma.
} 
prasłowiańskiego rdzenia już całkowicie się wycofało. Szczegółowe historyczne badania porównawcze pozwoliłyby wskazać, jakie czynniki wpłynęły na kierunki przekształceń w poszczególnych językach i w którym momencie drogi rozwojowe się rozeszły. Już na podstawie przedstawionych informacji można jednak postawić hipotezę o „wtórnej” parametryczności analizowanego przymiotnika. Jeśli zgodnie z danymi etymologicznymi uznamy, że w nim (i w jego zachowanych innosłowiańskich odpowiednikach) nośnikiem znaczenia leksykalnego był pierwotnie rdzeń ${ }^{*}$ grom-, to należałoby przyjąć, że nastąpił proces leksykalizacji.

\section{Rdzeń grom- w polskich derywatach z przedrostkiem o-}

Współcześnie budowa słowotwórcza przymiotnika ogromny jest zatarta, niełatwo również wskazać bezpośrednią podstawę słowotwórczą. Przykładowo w SGS przymiotnik ten stanowi centrum gniazda, będąc bazą dla derywatów: ogrom, ogromnieć, ogromniasty pot., przeogromny podn. albo żart., ogromnie. Zgodnie z założeniem słownika jest to ujęcie synchroniczne, które nie uwzględnia etymologii oraz historycznego rozwoju wyrazu. W wSJP PAN informacja o pochodzeniu (etymologii) przymiotnika ogromny odsyła do rzeczownika odczasownikowego ogrom, od dawnego przedrostkowego ogromić pochodnego od gromić. W przypadku wyrazów pochodnych odsyła się do wyrazu podstawowego (Żmigrodzki i in. (red.) 2018: 22), a zatem w przypadku przymiotnika ogromny odesłanie do rzeczownika ogrom informuje o pochodności słowotwórczej ogromny od ogrom. Uwzględniając pochodność gromić od grom, można utworzyć hipotetyczny następujący szereg derywacyjny: grom > gromić > ogromić $>$ ogrom > ogromny.

Trzy pierwsze takty derywacyjne (grom > gromić; gromić > ogromić oraz ogromić > ogrom) nie budzą zastrzeżeń ${ }^{13}$. W kontekście poczynionych rozważań etymologicznych wskazać można pochodność gromić od grom (np. SBo). Pochodność czasownika ogromić od gromić jest natomiast analogiczna jak w przypadku innych czasowników: okupić < kupić; okropić < kropić; okazać < kazać. Podobne serie derywacyjne można wskazać także dla innych formacji przedrostkowych od gromić: odgromić; pogromić; rozgromić; zgromić. Również pochodność ogrom od ogromić zaświadcza seria analogicznych przykładów: okaz < okazać; okup < okupić; okrag < okrążyć. Wśród wymienionych czasownikowych derywatów przedrostkowych od gromić wskazać można tylko dwie formy, tj. pogromić i ogromić, od których istnieją formy rzeczownikowe (pogrom i ogrom). Dane etymologiczne wskazują na pochodność ogromny bezpośrednio od ogromić (sBo). Obecność/nieobecność oraz frekwencja wyrazów ogromić, ogromny i ogrom w sstp i SPXVI każe się zastanowić nad zależnością słowotwórczą i semantyczną między nimi.

Spośród wyrazów z przedrostkiem $o$ - wywodzących się z rdzenia ${ }^{\star}$ grom- w staropolszczyźnie notowany jest tylko czasownik ogromić 'przestraszyć, napełnić trwogą' (sstp). Poświadczony został jednokrotnie w łacińskim cytacie: Nam plus solicitus labe fit attonitus, gl. territatus ogromyony 1466 (R XXII 19), dlatego na jego podstawie nie jest możliwy szerszy komentarz na temat znaczenia oraz funkcjonowania w staropolszczyźnie czasownika

$13 \mathrm{~W}$ przypadku ogromić możliwa jest również interpretacja jego budowy słowotwórczej jako czasownika odrzeczownikowego (zob. Krupianka 1969: 97-98). 
ogromić. Warto zauważyć, że znaczenie 'przestraszyć, napełnić trwogą' jest wtórne wobec znaczenia etymologicznego. W sstp znaczenie ogromić odnoszące się do grzmotu i huku nie jest notowane. Wprawdzie Aleksandra Krupianka w opisie formacji czasownikowych z przedrostkiem $o-(o b-) \mathrm{w}$ języku polskim podaje znaczenie 'rzucić grom', jednak - jak zaznacza - „[w] zabytkach XVI-wiecznych [występował on - dop. M.P., B.M.], zwłaszcza w znaczeniu oderwanym: «Tácy y nawiętszey światłości Bożey y ogromienia iego nie przyimuią» (Skar Żyw 8o)” (1969: 98). Badaczka uważa, że w formacjach typu ogromić „,formant przedrostkowy nawiązuje do podstawowej funkcji przedrostka $o$-(ob-), występującej w strukturach odczasownikowych, mianowicie wyraża «dookolność» odbywającej się czynności" (1969: 97). Klasyfikując ogromić jako formację odrzeczownikową, tak analizuje jej budowę słowotwórczą i określa funkcje tworzących ją formantów:

Nawiązując do struktury składniowej można powiedzieć, że formant przedrostkowy przy współudziale formantu przyrostkowego pełni tu funkcję orzeczenia wyrażającego czynność otoczenia, objęcia, okrycia, natomiast temat słowotwórczy porównać można do dopełnienia czynnika pomocniczego wyrażonego w narzędniku. Cała formacja funkcjonuje tu na zasadzie formuły: 'otoczyć czym' (Krupianka 1969: 98).

Dla dalszych rozważań ustalenie pochodności czasownika ogromić nie jest kwestią kluczową. Ważna jest jednak obserwacja, że w przypadku pochodności ogromić od gromić interpretacja znaczenia przedrostka $o$ - mogłaby wskazywać na czasownik, „w którym temat słowotwórczy pełni funkcję orzeczenia, a format przedrostkowy - funkcję okolicznika miary" (Krupianka 1969: 78-79). To tłumaczyłoby wykształcenie się znaczenia związanego z ilością, wielkością czy intensywnością w grupie derywatów z prefiksem $o$ - utworzonych od rdzenia * gromw późniejszych wiekach. O ile w przypadku czasownika ogromić (a także późniejszych derywatów ogromiony i ogromienie) znaczenie wnoszone przez o- można interpretować zarówno jak 'otoczyć czym', jak i 'nadmiernie, bardzo intensywnie', to wydaje się, że w wyrazach ogrom czy ogromny przedrostek $o$ - wnosi drugie $\mathrm{z}$ wymienionych znaczeń.

W polszczyźnie XVI wieku wyrazów z o- wywodzących się z rdzenia ${ }^{*}$ grom- jest więcej niż w staropolszczyźnie. Należą do nich: ogrom ${ }^{14}$, ogromić, ogromienie, ogromiony, ogromnie, ogromny, ogromno, ogromność. Ich frekwencja jest bardzo zróżnicowana: ogromić, ogromienie i ogromno mają pojedyncze poświadczenia, ogromność - 8, ogromnie - 11, natomiast ogromny - 93. Warto nadmienić, że autorzy SPXVI tylko przy haśle ogromić wskazali explicite, że jest to formacja wspólnordzenna do gromić. W przypadku pozostałych wyrazów zastosowali odnośnik $c f$, łącząc nim wyrazy ogrom i ogromność; ogromić, gromić, ogromienie i ogromiony; ogromnie i ogromno oraz ogromny i nieogromny. W rozważaniach na temat genezy parametrycznego znaczenia przymiotnika ogromny, a także semantyki innych wyrazów z przedrostkiem $o$ - wywodzących się z rdzenia ${ }^{*}$ grom-, ważna jest obserwacja, że wszystkie wyrazy charakteryzujące się wyższą frekwencją niż jednokrotne poświadczenie (tj. ogromność, ogromnie i ogromny) to wyrazy polisemiczne, mające pięć lub sześć znaczeń. 
Tabela. Znaczenie wyrazów ogromność, ogromnie i ogromny w SPXVI

\begin{tabular}{|c|c|c|c|}
\hline & \multicolumn{3}{|c|}{ WYRAZ } \\
\hline & ogromnie (11) & ogromność (8) & ogromny (93) \\
\hline 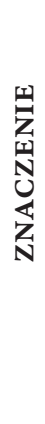 & $\begin{array}{l}\text { 1. 'Straszliwie, przerażają- } \\
\text { co' (2) } \\
\text { 2. 'Zadając ciosy, rażąc' (5) } \\
\text { 3. 'Okazale, wywołując wra- } \\
\text { żenie wielkości' (1) } \\
\text { 4. 'Donośnie, bardzo głośno, } \\
\text { mocno' (2) } \\
\text { 5. 'Obrzydliwie, odstręcza- } \\
\text { jąco' (1) }\end{array}$ & $\begin{array}{l}\text { 1. 'Wielkość, siła' (2) } \\
\text { 2. 'Wspaniałość' (3) } \\
\text { 3. 'Surowość, srogość' (1) } \\
\text { 4. prawdopodobnie } \\
\text { 'Wzbudzanie strachu' (1) } \\
\text { 5. 'Głośny huk' (1) } \\
\text { 6. ['Drżenie'] }\end{array}$ & $\begin{array}{l}\text { 1. 'Wielki; dużych rozmia- } \\
\text { rów; dużej liczebności; } \\
\text { mocny' (27) } \\
\text { 2. 'Wspaniały, okazały' (1) } \\
\text { 3. 'Bardzo głośny, donoś- } \\
\text { ny' (19) } \\
\text { 4. 'Budzący strach, trwogę, } \\
\text { przerażający' (35) } \\
\text { 5. 'Odrażający, brzydki' (8) } \\
\text { 6. 'Haniebny, niegodny' }\end{array}$ \\
\hline
\end{tabular}

Źródło: opracowanie własne.

Dane w tabeli pokazują, że w XVI wieku ogromnie, ogromność i ogromny funkcjonowały w znaczeniach nieznanych we współczesnej polszczyźnie, odnoszących się do huku, głośnego dźwięku; strachu czy zadawania ciosów. Ponadto SPXVI notuje znaczenia związane z ilością, wielkością i/lub intensywnością (w tabeli zaznaczyłyśmy je pogrubionym drukiem). W kontekście czynionych rozważań szczególnie interesujące są te znaczenia i konteksty użycia wyrazów ogromnie, ogromność i ogromny, które świadczą o nowej wartości semantycznej, niezwiązanej z pierwotnym znaczeniem. W sPXVI notowane są nieliczne przykłady tego typu wyrazów, tj. ogromnie (1) i ogromność (2) oraz ogromny (27).

Przysłówek ogromnie w znaczeniu 'okazale, wywołując wrażenie wielkości' zaświadcza cytat: na then czas Biskup / ubrat się byt ohromnie / w szatę szeroka / a bohata (GórnDworz P). W odniesieniu do ubioru biskupa znaczenie ohromnie 'okazale’ nie budzi wątpliwości. Można się jednak zastanowić, czy w tym przykładzie znaczenie 'wywołując wrażenie wielkości' jest na pewno adekwatne. Zwłaszcza gdy porównamy znaczenie ohromnie ze staroczeskim ohromnie 'ohromující, úžas působící' (pol. 'zadziwiająco, oszałamiająco'). Jeśli taka interpretacja znaczenia ohromnie jest właściwa, w materiale XVI-wiecznym nie byłoby poświadczenia wskazującego na parametryczne znaczenie ogromnie.

Dla dwóch przykładów ogromność w znaczeniu 'wielkość, siła' autorzy sPXVI podali następujące łacińskie odpowiedniki: enormitas, enormis magnitudo a. proceritas, immanis maximitas, moles za Thesaurusem (Knapiusz 1643). Informacja ta znajduje się w haśle ogrom potraktowanym przez Knapiusza jako synonim do ogromność: 'Enormis magnitudo. Enormis proceritas. Enormitas alicuius rei. Moles immanis alicuius rei.' (Knapiusz 1643). Pod względem słowotwórczym jest to „Apocope Polonica”, czyli „Ucinanie” (Puzynina 1961: 146) ${ }^{15}$. W przypadku

15 „Apocope Polonica” to jedna z figur gramatycznych stosowanych przez Knapiusza, którą przejął z prozodii łacińskiej. Przykładami są m.in. wyrazy: miłujem dla miłujemy, srog dla srogi, spad dla spadt, oń dla o niego. Knapiusz objaśnia tę figurę 
wyrazów ogrom i ogromność chodzi o znaczenie odnoszące się do wielkości i ilości wykraczających ponad normę (por. znaczenie enormis 'wykraczający ponad normę, nadmierny, niezwykle duży, wielki, ogromny' w Elektronicznym słowniku łaciny średniowiecznej w Polsce ${ }^{16}$ ).

Warto również dodać, że w Thesaurusie odnotowane są dwa osobne hasła ogrom. Pierwsze odsyła do haseł grzmot i okrzyk, natomiast drugie - do hasła wielkość w znaczeniu 'wielkość każdej rzeczy przyzwoita’ (Knapiusz 1643). Nadto Knapiusz nie definiuje przymiotnika ogromny, tylko stosuje odsyłacz do haseł srogi, straszny i wielki. Podsumowując uwagi o sposobach notowania wyrazów ogrom, ogromność i ogromny w Thesaurusie, należy podkreślić, że leksykograf rejestruje dwa hasła ogrom o różnych znaczeniach: ogrom (ogromność) i ogrom (grzmot, okrzyk), natomiast znaczenie ogromny wiąże ze znaczeniem parametrycznym. Wyraz ogrom wywodzi od ogromność, czyli wskazuje inny kierunek motywacji słowotwórczej niż słowniki etymologiczne.

Wracając do analizy XVI-wiecznego materiału poświadczającego użycie wyrazu ogromność w znaczeniu 'wielkość, siła, należy zauważyć, że SPXVI notuje wyrażenie ogromność wojenna poparte kontekstem: Moc jego będzie w niezliczonych Anielskich wojskach / ktorzy pojda rozszykowani jako do bitwy / ze wszytkim rynsztunkiem / i armatal i broniami / i ogromnościa wojenna (SkarKaz 6a). Drugi przykład pochodzi z dzieła Górnickiego: a ktore źwierzęta wielkościa podniosłe / i rozszerzone stanęty / tedy tym onęż ogromność / onęż wielkość dał ku obronie (GórnRozm Nv). Interpretacja znaczenia ogromność w obu przykładach nie jest jednoznaczna. Gdy mowa o ogromności wojennej, nie do końca wiadomo, co miałoby oznaczać to wyrażenie. Nasuwa się przypuszczenie, że być może chodzi tu o znaczenie związane z 'głośnym hukiem', w takim kontekście ogromność wojenna oznaczałaby 'wrzawę wojenną. W drugim cytacie prawdopodobnie ogromność oznacza 'siłę.

Frekwencja przymiotnika ogromny w SPXVI w znaczeniu 'wielki; dużych rozmiarów; dużej liczebności; mocny’ wynosi 27. Autorzy słownika wskazują m.in. następujące jego łacińskie odpowiedniki: terribilis, centenarius, colosseus, conspicuous, magnitudine, duplex, enormis, grandis, immanis, ingens, magnus, milliarius, multus, numerosus, pergrandis, pluralis, vastus, vehemens. Przytoczone wyrazy świadczą o szerokim, i jednocześnie nieostrym, zakresie znaczeniowym przymiotnika ogromny. Na podstawie tłumaczenia wybranych łacińskich odpowiedników można wskazać jeszcze inne - poza wymienionymi w definicji - określenia, na przykład: olbrzymi, niezmierny, wykraczający ponad normę, bardzo wielki, obszerny, rozległy, liczny, bardzo wielu, mnóstwo, bardzo, zbyt, wspaniały, okazaly ${ }^{17}$.

Dodatkowego komentarza wymagają poświadczenia przymiotnika ogromny wskazujące na znaczenie parametryczne odnotowane w SPXVI: Tetricus, Gora jest we włoszech (sic!) barzo ogromna i przykra (Mącz 453b). Przykład ten w opinii twórców SPXVI potwierdza znaczenie

słowami: „Item figura grammatica, literam vel syllabam fini dictionis adimens”. Inne figury gramatyczne w Thesaurusie to np. „Apheresis Polonica”, czyli „Odjęcie”: mu dla jemu, ki, ka dla jaki, jaka; „Epenthesis Polonica”: południe dla półdnie, zdejmuje dla zejmuje, zjął; „Paragoge Polonica”: leżący dla leżac, syniec dla syn, serzec dla ser (Puzynina 1961: 146).

16 https://elexicon.scriptores.pl/pl/lemma/ENORMIS\#sense_II (dostęp: 21 sierpnia 2020).

17 Polskie znaczenia podano za Elektronicznym słownikiem łaciny średniowiecznej w Polsce (hasła: amplus, enormis, immanis, immensus, ingens, magnus, multum, peramplus, permagnus). 
'wielki; dużych rozmiarów; dużej liczebności; mocny', jednakże obecność intensyfikatora barzo w prepozycji w stosunku do połączenia ogromna i przykra, każe się zastanowić, czy nie chodzi tutaj o znacznie 'budzący strach, trwogę, przerażający'. Jeśli jednak faktycznie przymiotnik ogromny w tym kontekście ma znaczenie parametryczne, jego łączliwość była inna niż współcześnie (obecnie „biegunowy” przymiotnik ogromny nie łączy się z bardzo). Pozostałe przykłady zaświadczają m.in. znaczenie dużej liczebności, na przykład ogromne wojsko (Tam acz was w liczbie dosyć niewiele było/ z ogromnym wojskiem Wołoskim / i Tureckim / nie tylo Harce I ale i potkę́cie mieli (BiałKaz L4)) czy 'wielki, dużych rozmiarów', na przykład ogromne wały (Teraz kędzierze nastrzępi / w godzinie Dnem wzgorę (sic!) stanie / a ogromne waly Wysokich będą obłokow sięgały (KochPieś 49)).

Spośród 93 poświadczeń przymiotnika ogromny w SPXVI jednokrotnie odnotowana jest forma ohromny: Dzwońże mily Zygmuncie / tymi trzemi głosy / A niech twoj ohromny brzęk i bije ludziom w nosy (RejZwierz 105). Przymiotnik ten użyty został w znaczeniu 'bardzo głośny, donośny’. Zapis ohromny i znaczenie odnoszące się do dźwięku wskazuje na wpływ czeski.

Analiza trzech poświadczeń wyrazów ogromnie i ogromność pokazuje, jak niełatwym zadaniem jest interpretacja ich wartości semantycznej w polszczyźnie XVI wieku. Na podstawie wskazanych kontekstów trudno jednoznacznie potwierdzić funkcjonowanie analizowanych wyrazów w znaczeniu parametrycznym. Wprawdzie lektura poszczególnych artykułów hasłowych w SPXVI pomaga odczytać sens dawnych jednostek leksykalnych - bądź wskazać ich możliwą interpretację, lecz nie daje pełnej odpowiedzi na pytanie o drogę rozwoju parametrycznego znaczenia przymiotnika ogromny ${ }^{18}$.

W niniejszym artykule przeprowadzone analizy koncentrowały się na ustaleniu genezy znaczenia parametrycznego przymiotnika ogromny. Dane językowe dowiodły, że pojawia się ono w polszczyźnie w XVI wieku, współwystępując ze znaczeniami wynikającymi z etymologii (zob. tabela). Dalszy rozwój semantyczny tego przymiotnika polega na wycofywaniu się znaczeń nieparametrycznych aż do współczesności. Ustalenie czasu zaniku poszczególnych znaczeń nieparametrycznych może stać się przedmiotem odrębnych badań.

\section{Zakończenie}

Przedstawiony wywód pozwala na sformułowanie następujących konkluzji, które mają zarówno charakter szczegółowy (a-d), jak i bardziej ogólny (e-f):

(a) ogromny jest przymiotnikiem parametrycznym wtórnym, to znaczy jego wartość parametryczna ukształtowała się w trakcie rozwoju semantycznego, nie wynika bezpośrednio ze znaczenia etymologicznego (inaczej niż np. w przypadku przymiotnika wielki ${ }^{19}$ );

(b) historyczna analiza semantyczna przymiotnika ogromny pozwala przypuszczać, że analogiczny rozwój dokonuje się w przypadku innych przymiotników, które współcześnie występują zarówno w znaczeniu parametrycznym (potworny ból, straszny głód, szalony apetyt), jak

18 Według ustaleń S. Kochmana semantyka przymiotnika ogromny ukształtowała się w języku czeskim, skąd została przejęta do polszczyzny (1975: 101)

19 Zgodnie z danymi etymologicznymi (SBo) prasłowiańskie velikz miało znacznie 'bardzo duży, wielki'. 
i nieparametrycznym (potworna zbrodnia, straszny widok, szalony czyn). Wymienione przymiotniki mają swoje ekwiwalenty o znaczeniach nieparametrycznych, podczas gdy ogromny ustabilizował swoje znaczenie tylko jako parametryczne;

(c) rozwój semantyczny przymiotnika ogromny jest ilustracją uniwersalnego fenomenu językowego, jakim jest leksykalizacja ${ }^{20}$, rozumiana jako blaknięcie znaczenia pierwotnego (Brinton, Traugott 2005). W jego przypadku „wyblakło” znaczenie związane ze zjawiskiem atmosferycznym. Dodatkowym argumentem przemawiającym za taką interpretacją jest zatarcie się wyrazistości semantycznej poszczególnych elementów morfologicznych, co pokazała analiza słowotwórcza;

(d) analiza historyczna przymiotnika ogromny dowodzi, że parametryczny element znaczenia nie był w nim od początku obecny i pojawił się najprawdopodobniej dopiero w XVI wieku, a następnie - wraz z wycofywaniem się znaczeń wynikających z etymologii - stopniowo umacniał swoją pozycję;

(e) tworzenie się wtórnych przymiotników parametrycznych każe się zastanowić nad procesem powstawania intensyfikatorów (ogromny v. ogromnie); zagadnienie to wymaga dokładnej kwerendy w źródłach historycznych;

(f) historyczne badania semantyczne w centrum zainteresowania stawiają zmianę językową, odnosząc się do form zachowanych w leksykonach i tekstach lub do form rekonstruowanych; koniecznym ich uzupełnieniem powinny być analizy uwzględniające wpływ czynników zewnętrznych (np. języków obcych, sytuacji literackiej, uzusu językowego w danej epoce).

Ujęcie pragmalingwistyczne, uwzględniające szeroki kontekst danego aktu komunikacji oraz charakterystykę nadawcy i odbiorcy, dopełniłoby opis zmiany językowej, której przykładem jest kształtowanie się znaczenia parametrycznego przymiotnika ogromny.

Bibliografia

Bańkowski A. 2000: Etymologiczny słownik języka polskiego, t. 1-2, Wydawnictwo Naukowe PWN, Warszawa.

Basaj M., Siatkowski J. 2006: Bohemizmy w języku polskim. Słownik, Wydział Polonistyki Uniwersytetu Warszawskiego, Warszawa.

Bezlaj F. 1982: Etimološki slovar slovenskega jezika, t. 2, Slovenska akademija znanosti in umetnosti, Inštitut za slovenski jezik, Mladinska Knjiga, Ljubljana.

Brinton L., Traugott E. 2005: Lexicalization and language change, Cambridge University Press, Cambridge.

Buttler D. 1978: Rozwój semantyczny wyrazów polskich, Wydawnictwa Uniwersytetu Warszawskiego, Warszawa.

Elektroniczny słownik łaciny średniowiecznej w Polsce (online: https://elexicon.scriptores.pl, dostęp: sierpień 2020 - styczeń 2021).

ÈssÂ: Ètimologičeskij slovar' slavânskih âzykov. Praslavânskij leksičeskij fond, t. 1-41, red. O. Trubačëv i in., Nauka, Moskva $1974-2018$.

ESUM: Etimologičnij slovnik ukraïns'koï movi, red. O.S. Mel’ničuk, t. 1-7, Naukova dumka, Kiïv 1982-2012. Hrvatski jezični portal (online: http://hjp.znanje.hr/index.php?show=search, dostęp: listopad 2020).

20 O leksykalizacji na materiale języka polskiego pisała Magdalena Pastuchowa, zob. np. Pastuchowa 2011. 
Jakubowicz M. 2010: Drogi słów na przestrzeni wieków. Zarys słownika motywacji semantycznych na materiale przymiotników słowiańskich odziedziczonych z prasłowiańszczyzny, Slawistyczny Ośrodek Wydawniczy, Warszawa.

Kleszczowa K. (red.) 1996: Słowotwórstwo języka doby staropolskiej. Przegląd formacji rzeczownikowych, Wydawnictwo Uniwersytetu Śląskiego, Katowice.

Kleszczowa K. 1998: Staropolskie kategorie słowotwórcze i ich perspektywiczna ewolucja. Rzeczowniki, Wydawnictwo Uniwersytetu Śląskiego, Katowice.

Knapiusz G. 1643: Thesaurus Polono-Latino-Graecus, Kraków (online: https://bc.pionier.net.pl/details/nnTtrff, dostęp: wrzesień 2020 - listopad 2021).

Kochman S. 1975: Polsko-rosyjskie stosunki językowe od XVI do XVIII w. Słownictwo, Opolskie Towarzystwo Przyjaciół Nauk, Zakład Narodowy im. Ossolińskich, Opole-Wrocław.

Krátky slovník slovenského jazyka (online: www.juls.savba.sk, dostęp: wrzesień 2020 - styczeń 2021).

Krupianka A. 1969: Formacje czasownikowe z przedrostkiem o-(ob-) w języku polskim, Państwowe Wydawnictwo Naukowe, Toruń.

Laskowski R. 1977: Od czego lepszy jest lepszy?, „Język Polski” LVII, z. 5, s. 323-334.

Machek V. 1957: Etymologický slovník jazyka českého, Nakladatelství československé akademie věd, Praha.

Mitrenga B. 2014: Zmysł smaku. Studium leksykalno-semantyczne, Wydawnictwo Uniwersytetu Śląskiego, Katowice.

Pastuchowa M. 2011: Leksykalizacja wobec tradycji językowej, „Annales Universitatis Paedagogicae Cracoviensis”, Studia Linguistica VI, Dialog z tradycją, cz. 1, Kraków, s. 244-254.

Pawelec D. 2003: Dzieje sztuki. Leksemy i pojęcia, Wydział Polonistyki Uniwersytetu Warszawskiego, Warszawa.

Puzynina J. 1961: „Thesaurus” Grzegorza Knapiusza: siedemnastowieczny warsztat pracy nad językiem polskim, Zakład Narodowy im. Ossolińskich, Wrocław-Warszawa-Kraków.

Rejzek J. 2001: Český etymologický slovník, Voznice, Leda.

SBo: W. Boryś, Słownik etymologiczny języka polskiego, Wydawnictwo Literackie, Kraków 2005.

SBr: A. Brückner, Słownik etymologiczny języka polskiego, Wiedza Powszechna, Warszawa 1927/1985.

SEsł: F. Sławski, Słownik etymologiczny języka polskiego, t. 1-5, Towarzystwo Miłośników Języka Polskiego, Kraków 19521982.

SGS: T. Vogelgesnag, Słownik gniazd słowotwórczych współczesnego języka ogólnopolskiego, t. 1, Gniazda odprzymiotnikowe, Universitas, Kraków 2001.

Siatkowski J. 1965: Bohemizmy fonetyczne w języku polskim, cz. 1, Zakład Narodowy im. Ossolińskich, Wydawnictwo Polskiej Akademii Nauk, Wrocław-Warszawa-Kraków.

SJPDor: Słownik języka polskiego, red. W. Doroszewski, t. 1-11, Państwowe Wydawnictwo Naukowe, Warszawa $1958-1969$. Skok P. 1971: Etimologijski rječnik hrvatskoga ili sprskoga jezika, t. 1, Jugoslavenska akademija znanosti i umjetnosti, Zagreb. Slovník spisovného jazyka českého (online: https://ssjc.ujc.cas.cz, dostęp: wrzesień 2020 - styczeń 2021).

Slovnik ukraïns'koï movi (online: http://ukrlit.org/slovnyk, dostęp: wrzesień 2020 - styczeń 2021).

SMań: W. Mańczak, Polski słownik etymologiczny, Polska Akademia Umiejętności, Wydział I Filologiczny, Kraków 2017. SP: Słownik prasłowiański, red. F. Sławski, t. 1-8, Zakład Narodowy im. Ossolińskich, Wrocław, 1974-2001.

SPXVI: Słownik polszczyzny XVI wieku, red. M.R. Mayenowa (t. 1-34), K. Mrowcewicz (t. 35-38), t. 1-22, Zakład Narodowy im. Ossolińskich, Wydawnictwo Polskiej Akademii Nauk, Wrocław-Warszawa-Kraków 1966-1994, t. 23-38, Instytut Badań Literackich Polskiej Akademii Nauk, Warszawa 1995-2020.

sstp: Słownik staropolski, red. S. Urbańczyk, t. 1-9, Zakład Narodowy im. Ossolińskich, Wydawnictwo Polskiej Akademii Nauk, Wrocław-Warszawa-Kraków 1953-1987, t. 10-11, Instytut Języka Polskiego Polskiej Akademii Nauk, Kraków 1988-2002.

Staročeský slovník (online: https://vokabular.ujc.cas.cz/, dostęp: wrzesień 2020 - styczeń 2021).

UsJP: Uniwersalny słownik języka polskiego, red. S. Dubisz, t. 1-4, Wydawnictwo Naukowe PWN, Warszawa 2008.

Vasmer M. 1950-1958: Russisches etymologisches Wörterbuch, Carl Winter Universitätsverlag, Heidelberg.

Witczak K.T. 2020: Rozważania nad etymologia gromu, „Poradnik Językowy” z. 10, s. 9-19.

WSJP PAN: Wielki słownik języka polskiego PAN, red. P. Żmigrodzki (online: https://wsjp.pl; dostęp: wrzesień 2020 - styczeń 2021).

Żmigrodzki P., Bańko M., Batko-Tokarz B., Bobrowski J., Czelakowska A., Grochowski M., Przybylska R., Waniakowa J., Węgrzynek K. (red.) 2018: Wielki słownik języka polskiego PAN. Geneza, koncepcja, zasady opracowania, Instytut Języka Polskiego Polskiej Akademii Nauk, Kraków. 
44 | ARTYKUŁY I ROZPRAWY | J̨̨ZYK POLSKi | CI 4

Summary

\section{The evolution of the parametric meaning of the adjective ogromny ('enormous') - a diachronic overview}

Keywords: history of Polish language, etymology, historical word formation, historical semantics.

The article concentrates on the development of the Polish adjective ogromny which, in contemporary Polish, has a parametric meaning only. The research is conducted in a historical frame which means that the starting point were the etymological and historical word formation data. We treat the information referring to the use of this adjective in the old texts and its presence in other Slavonic languages as complementary. Our analyses led, inter alia, to the following conclusions: - the parametric value of the adjective ogromny is secondary - it took shape during the history of Polish language; the main mechanism in the development of parametric value of ogromny is lexicalization. Its determinant is, in that case, the semantic fading and blurring of morphological boundaries. 